\title{
The Generation Mechanism for the Long-term Coexistence of China's Sound Film and Silent Film
}

\author{
Yunpeng Feng \\ College of Literature and Journalism \\ Sichuan University \\ Chengdu, China 610065
}

\begin{abstract}
The complicated situation of the long-term coexistence between China's sound film and silent film in the 1930s involved many aspects such as technological changes, market patterns, and the context of public opinion. The dominant and common factor of this complex mechanism is that film is regarded as the industry. This kind of industry has the double positioning of the purpose of commercial profitability and the national state's construction appeal. Under its influence, the popularization process of China's sound film depends on whether it can provide greater market space and exert more effective social influence.
\end{abstract}

Keywords-sound film; silent film; generation mechanism; film industry

\section{INTRODUCTION}

The 1930s was the transition period from Chinese silent films to sound films. From the initial production to full-scale popularization of sound films, China's sound films and silent films coexisted for seven years (1931-1937), thus forming an important cultural landscape and film phenomenon in the history of film in China. Why does this special movie phenomenon appear in the development of China's film? Is this phenomenon only caused by the single-dimension reform dilemma of film technology? If not, what other factors are involved in the process of generating this phenomenon? How do they correlate to each other and work together? To respond to the special film phenomenon that sound films and silence films coexist for a long time in the history of China's film, we need to comprehensively examine it from various aspects. On the basis of sorting out the existing research results, this paper attempts to outline and explain the generation mechanism for the special phenomenon of long-term coexistence of sound films and silent films in the history of China's films from the aspects of economy, technology, concept, and culture of China's films at that time by collecting and analyzing original data.

\section{THE PATH OF CHANGE FROM PROJECTION TO}

\section{PRODUCTION AND THEN TO TECHNOLOGY DEVELOPMENT}

The development of film from silent film to sound film is based on technological innovations, although most of time these technological innovations originally took place outside the film field, or did not aim for film change. The path of change in American sound films was that after technology research and development was basically successful, these technological innovations were rapidly incorporated into the film industry and experienced a process from technological research and development to innovative application and popularization. Warner Bros. and Fox Corporation successively obtained market profits through sound films. Paramount and Rockwell also quickly signed a cooperation agreement with Western Electric Corporation in May 1928, followed by the popularity of the sound movie driven by market profits in the United States. The projection of U.S. sound films in China has greatly promoted the technological transformation of China's films, and has participated in the generation mechanism of China's sound films as an important market and technological factor. The transformation of China's sound films started from the field of projection, and then entered the stage of technological development. So why and how did China's sound films have formed such a transformation path? How does this path of change affect the transitional period of China's sound films?

Before 1929, various movie theaters in Shanghai were not equipped with projection equipment for sound films. However, the multiple projection of short sound films and news films at the time promoted technological innovation in the field of projection. In January 1929, Xialingpeike Film Theatre installed the sound film projection device of the Arsey Aifutuofeng Company, and in February the same year the United States film "Flight General" was projected. In the second half of 1929, Daguangming Theater, Guanglu Theatre, Carlton Theatre, and Audi Orbitian Theater in Shanghai installed sound film projection equipment and successively displayed "happy and tragic", "The Gore Gore Girls" and "come out in the wash", and "Patriot Boy" and other audio films. Since then, because of the development of sound film production, Shanghai's small and medium-sized movie theaters have also been equipped with sound devices. As for the new movie theaters, it is natural that sound machine is an essential part of the equipment. ${ }^{1}$

The Daguangming Cinema began to display Time Warner Inc's vita style film "both happy and tragic" from September 3, 1929, and added Mu Weitong's short video "Speech of Chiang Kai-shek". The Guanglu Theatre began to show vita style film "The Gore Gore Girls" from September 7, 1929. Then the Carlton Theatre began to show the United Artists Company film "The Falling Stones" on September 13, 1929; the Odian Theatre began to display Paramount film "The Patriot" on December 
Capital investment, technical personnel, experimental facilities, and industrial systems are all important conditions for the development of film sound technology. In the face of this technological change, China's films will either started technological research and development, "or wait and gather more information on the potential of technology and the public's acceptance of innovation, or first put new products or processes on the market to obtain very competitive impact." ${ }^{2}$ The needs of the market competition in the film industry and the actual conditions of technical conditions have prompted China's films to temporarily skip the stage of technological development and directly enter the stage of revolutionary application of film sound technology. By examining several films in the pilot stage of China's sound film, it is found that this innovative path undoubtedly aggravates the dependence of Chinese films on foreign technology and the risk of market investment.

"Consort Yu" produced by Union company was collected by the Great China Record Company while Japan controlled the patent of audio equipment. At the same time, the charges for sound recording on each side of wax disc of the Great China Record Company are as high as 500 yuan. Due to economic conditions, Union company "had to gather the important dialogues and singing" and only recorded ten sounded wax discs. "For other parts, they used Cantonese music 'Wanda Tsai', 'The Palm-leaf Beated by Raindrop', 'three pools mirroring the moon', 'Reserved Snow on the cold River' and 'The Princess' Lament' to assist the sound. ${ }^{3}$ Tianyi Company is relatively active in the standpoint of trial production of sound film, but factors such as capital, technology, talents, and equipment also limit the production of sound film. For example, during the trial production of "Pleasures of the Dance Hall", in addition to the high salary of foreign technicians, the filming process was also fraught with setbacks. When the sound engineer collected the sound, the sound wave of the radio station nearby was also included in the film. Therefore, Tianyi Company "needs not only to postpone the date but also to increase the cost" in "Table I". ${ }^{4}$

5, 1929. see Zhi Song, "History of Shanghai Movie Theater Showing Sound Film", "Electroacoustic", Vol. 5, No. 36, 1936.

(United States) Robert C. Allen, Douglas Gomel, "Film History: Theory and Practice", Beijing: Beijing Union Press, 2016, 135-136.

Xu Bibo, "The Beginning of Chinese Sound Films," Chinese Film, 4th Issue, 1957.

4 Xu Bibo, "The Beginning of Chinese Sound Films," Chinese Film, 4th Issue, 1957.
TABLE I. CHINA'S EARLIER WORKERS FOR SOUND FILM AND TECHNICAL EQUIPMENT

\begin{tabular}{|l|l|l|}
\hline \multicolumn{1}{|c|}{ film } & \multicolumn{1}{|c|}{ staff } & \multicolumn{1}{|c|}{$\begin{array}{l}\text { sound collecting } \\
\text { organization and } \\
\text { devices }\end{array}$} \\
\hline $\begin{array}{l}\text { Sing-song Girl } \\
\text { Red Peony }\end{array}$ & photographer: Dong Keyi & Pathé Orient \\
\hline Consort Yu & $\begin{array}{l}\text { photographer: Liu } \\
\text { Liangchan }\end{array}$ & $\begin{array}{l}\text { Greater China records } \\
\text { Company }\end{array}$ \\
\hline $\begin{array}{l}\text { Blue Sky after } \\
\text { Raining }\end{array}$ & photographer: K·Henry & $\begin{array}{l}\text { Japan Sound Film } \\
\text { Company }\end{array}$ \\
\hline $\begin{array}{l}\text { Pleasures of the } \\
\text { Dance Hall }\end{array}$ & $\begin{array}{l}\text { photographer: Bert Cann } \\
\text { Sound engineer: Leo } \\
\text { Britton, Byran C.Guerin }\end{array}$ & America Movietone \\
\hline $\begin{array}{l}\text { In the Old } \\
\text { Beijing }\end{array}$ & $\begin{array}{l}\text { photographer: Jack Smith, } \\
\text { James Williamson, and } \\
\text { Dong Keyi }\end{array}$ & Sidatong \\
\hline
\end{tabular}

Because of being controlled by others in many aspects, China's film and industry sectors have begun to actively study and explore sound film technology. During this period, Zhou Jianyun, Situ Huimin, Xu Bibo, Yang Minshi, Shen Gao, Li Yulin and other talents in domestic film and intellectual circles actively introduced and explored the historical and technological principles of the invention of sound films. They wrote articles in the titles of "historiette", "brief history", "introduction", "research", "description", "historical site", "theory" and "elementary introduction" and published in the newspapers and periodicals magazines such as "Monthly Film Bulletin" and "Journal of Industrial and Commercial", "light guide Weekly" and "Jianghan Trend Monthly", which have greatly promoted the development, application and popularization of film sound technology.

By adopting methods such as improving foreign equipment and self-developing, the China's film industry began to try to get rid of dependence on foreign sound film technology and market control caused by technology patents. In terms of technical talents, star company and Tianyi Company began to dismiss foreign workers. In the field of technical equipment, the development of recording equipment such as "Sidatong", "Aisitong", "Qingxianshi", "Hemingtong", "Three Friends", "Zhonghuatong" and "Zongyitong", etc. The establishment of a batch of domestic film machinery companies, such as the Chinese and Western Film Corporation, Dalai Machine Factory, Dentsu Film Equipment Manufacturing Company, and Zengtai Film Machinery Factory, provided technical support for the popularity of China's sound films. In terms of production, the "In the Old Beijing" (Sidatong), "Willows in Spring" (Qingxian shi), and "The Torrents of Spring" (He Mingtong) were successively filmed successfully. The "Three Friends" film recorder jointly developed by Situ Yi, Situ Huimin, and Ma Dejian recorded episodes for films such as "Song of the Fishermen", "Avenue", "New Woman" and "Plunder of Peach and Plum". The star company used "Mosstom" of Shanghai Asia Electric Company to record "Cross Street" and "Street Angel".

Despite the difficulties in funds, technology, equipment, talents and many other aspects, driven by market competition, China's sound films have started from the field of production. To get rid of the dependence on foreign raw materials and talents, it is imperative for the Chinese film industry to 
develop technology for sound film and train talents. However, independent technological research and development and equipment manufacturing also require a long time and a huge amount of capital expenditure. At that time, the social background and the ecology of China's films further increased the complexity of this process. The special phenomenon of the long-term coexistence of China's sound films and silent films is not merely due to the limitations of single-dimensional film technology.

\section{THE MONOPOLISTIC SITUATION OF EXTRUSION OF FOREIGN CAPITAL AND INTERTWINING OF A NUMBER OF DOMESTIC PRODUCTION COMPANIES}

Around the 1930s, the market structure of Chinese films developed and changed on the basis of continuing the situation in previous stage. On the one hand, foreign capital still occupies the major domestic film market, but it has shifted from the monopoly of the entire film system to the control of the distribution and projection system. On the other hand, domestic production companies have initially formed the monopolistic situation dominated by three companies, namely Lianhua, Tianyi, and Star through public opinion campaigns, monopolization policies, mergers and acquisitions, and market competition. The market pattern of co-existence of extrusion of foreign capital and many production companies has greatly affected the appearance of the China's sound film production period.

Around this period, foreign film companies monopolized the distribution and projection of China's film markets by exporting films to China, setting up special distribution agencies, and controlling China's first round of cinemas. As far as film input is concerned, according to the US Department of Commerce's sales statistics report on the importation of American film to East Asia, up to December 1, 1930, the sound films input to China accounted for $50.6 \%$ and silent films accounted for $49.4 \%$. At that time, there were 233 Chinese cinemas, of which 40 were sound cinemas. 5In 1933, 1934, and 1935, the number of Hollywood films imported into China was 355,345 , and 328 respectively. ${ }^{6}$ In terms of distribution, in order to facilitate the further exploitation of the Chinese film market, from 1926 to 1937 , the eight major movie companies in the United States set up specialized distribution agencies in Shanghai, and issued them through various means such as Chinese and foreign newspapers, posters, pictures, neon signs and other means. The projection turn-projection area-bye system formed by Hollywood film companies in the market competition enables it to gain monopoly status in the field of projection without having to control all the projection channels in China. The foreign capital has become an important obstacle to the generation of Chinese sound films through the combination of patent sharing, patent control, and control of first-round and second-round cinemas.

See Ping Baoshan, "Sound Films in East Asia", "The Life of Film", Vol. 1, No. 9, 1931.

$$
6 \text { See Rao Shuguang, "The History of Chinese Film Market }
$$

Development", Beijing: China Film Press, 2009, p. 103.
The wax disk dubbing sound film "Consort Yu" of Union Film Company was originally planned to be screened at the Carlton Grand Theatre. However, due to the contract issue involving Western Electric Company, the owner of the Union failed to negotiate, and finally it changed to use Xialingpeike theatre with higher rent instead of West Electric In 1935, the Great Light Theater known as "The First Theater in the Far East" screened the film "Fantastic" of Lianhua Film Co., Ltd., but the screening conditions were harsh: the mirror stage was only two days, and the account is divided into $80 \%$ for theater and $20 \%$ for film companies. In the end, due to the active struggle of Luo Mingyou, they achieved the dividing method of $70 \%$ for the theater and $30 \%$ for the film company. Chinese movie companies have chosen to perform test screenings or public screenings in first-run cinema for a variety of reasons, including expanding influence, profit appeals, and screening conditions. However, this also implies harsh screening terms and splitting ratios, which directly restricts the ability and capital of China's film company to expand reproduction economically. ${ }^{7}$

In the late 1920s, domestic production companies initially formed a large-scale production and operation model under the influence of the internal and external environment of the film industry. Some production companies have gradually expanded their scales through capital raising, improving management, and reforming business strategies, etc., and began to form a structure in which three film companies, Lianhua, Tianyi, and Star, jointly dominate the market. These movie companies used various strategies to maintain their monopoly position in the domestic film industry structure, occupying only a small part of the film market share except those controlled by foreign companies. Under this background, the attitudes and positions of these companies on the sound film, their production strategies and business strategies, and the quantity, quality, and market effects of their sound film productions have also determined the ecology and pattern of China's sound films at this stage in "Table II"8. life in "Guang Lu" on March 3rd, 1931. On March 15th of the same year, it was premiered in "Xinguang"; "Consort Yu" was premiered in "Xialingpeike" on May 24, 1931. "Blue Sky after Raining" was test screened at "Xinguang" on June 21, 1931, and premiered on July 1. "Pleasures of the Dance Hall" was previewed in "Guang Lu" on October 7, 1931, and On October 10th of the same year, it was also shown in two theaters, "Guanglu" and "Nanjing". At the end of January 1932, "In the Old Beijing" was premiered in "Carlton". See Xu Bibo: "The Beginning of China's Sound Films", "China Film", Issue 4, 1957.

According to the Filmography in "The Development History of China's Film" compiled by Cheng Jihua, for the convenience of statistics, a number of films produced by various companies in the same year were used as one. "Other" companies include films produced by film companies in Shanghai, Beijing, Tianjin, and Guangzhou. 
TABLE II. Production Volume of Sound Films by Major China's Movie COMPanies From 1931 to 1937

\begin{tabular}{|l|l|l|l|l|l|l|l|}
\hline \multicolumn{1}{|c|}{ company name } & $\begin{array}{c}\text { Star } \\
\text { Company }\end{array}$ & $\begin{array}{c}\text { Tianyi } \\
\text { Company }\end{array}$ & $\begin{array}{c}\text { Lianhua } \\
\text { Company }\end{array}$ & $\begin{array}{c}\text { Yihua } \\
\text { Company }\end{array}$ & $\begin{array}{c}\text { Xinhua } \\
\text { Company }\end{array}$ & $\begin{array}{c}\text { Diantong } \\
\text { Comany }\end{array}$ & others \\
\hline Number of sound films & 36 & 31 & 13 & 16 & 13 & 4 & 30 \\
\hline Total film production & 97 & 48 & 75 & 22 & 13 & 4 & 120 \\
\hline
\end{tabular}

Because Tianyi Company used sound projection equipment at some of the theaters in Nanyang earlier, it was very positive to the production of sound film. "Since the 20th year of Republic of China, they have purchased Muweitong audio-visual radio, especially for shooting sound film. By the 22th year, they restore the silent part and shoot both sound film and silent film. "In early 1930, the short film "bells" has been trial produced, but unfortunately it was destroyed in the fire before screening. In 1931, it began to trial produce sound film "Pleasures of the Dance Hall" and on October 10th of the same year it was shown in two theaters in Shanghai Guanglu cinema and Nanjing cinema. From 1931 to 1937, Tianyi Film Company produced a total of 48 films, including 31 sound films.

In response to the rapid rise of Tianyi Company and Lianhua Company, the Star Company made the decision of "developing film technology, raising filmmaking standards, regaining its leadership position and consolidating the honor of "star"”. Wax disk dubbing sound film "Sing-song Girl Red Peony" brought huge commercial profits to Star Company. In the Nanyang market alone, Shanghai Far East Company, on behalf of the Philippine Studios, purchased the show rights for this area at 18,000 yuan. Youth companies acquired the screening right of Indonesia at $\$ 16,000$. The Star Company's original price was 14,000 yuan, and the market price of the two silent films in Nanyang was between 1,000 yuan and 2,000 yuan. ${ }^{10}$ Driven by profits, the star company sent Hong Shen to the United States to purchase sound film equipment and employ technical talents. However, the subsequent box office losses in "In the Old Beijing" and "The Fatal Irony", as well as the huge indemnities caused by the copyright disputes of "The Fatal Irony" made Star Company have reservations about the production of sound films to a certain extent. From 1931 to 1937, the star company produced a total of 97 films, with 36 sound film, including 3 sound cartoons including "Camel Dance", "The Fortune Cookie" and "resistance."

Although Lianhua Films has four studios and a huge film distribution network, and began producing sound films in 1930, the company's production strategy of "Reviving China's Film" and the negative attitude of the leading figure, Luo Mingyou for sound films have prompted Lianhua to shoot a large number of silent films by using the market vacancy of silent film caused by the sound film of the United States screening in China. Luo Mingyou believes that with the rise of sound films, "the producer of silent films in the U.S. system is going fewer. The source of the film will be cut off, and the non-sound film theaters will have no film to screen. "Afterwards, most theaters will only use sound film

\footnotetext{
Mingyi, "The Overview of Tianyi Company and General Production", "Jincheng Monthly" Volume 1, Number 4.

$10 \quad \mathrm{Xu}$ Bibo, "The Beginning of Chinese Sound Films," Chinese Film, 4th Issue, 1957.
}

as appeal." "Inder such an attitude and production policy, Lianhua Film Company produced seventy-five films in 1931-1936, but only 13 sound films. However, at this stage, Lianhua Film Company produced China's classic silent films such as Love and Obligation, Night in the City, Gadgets, and Goddess. In addition, the emerging "Yihua", "Xinhua" and "Diantong" also actively participate in the market competition by producing sound films at this stage.

It can be said that although the sound film is ostensibly a major transformation of the film based on technological change, it is first appeared as a business in the world. In the market where U.S. film controlled the field of projection, how to seize the opportunity to acquire and maintain its monopoly position has become a key issue faced by many Chinese film companies at that time. On the one hand, a large number of U.S. audio films have been imported into China, prompting the replacement of sound projection equipment in high-grade cinemas, while domestic film companies are temporarily unable to produce sound films. Under this circumstance, the trial production of the sound film has provided domestic film companies with an important way to differentiate product market and gain market competition. On the other hand, since the production of sound film requires several times the cost of silent films, many domestic cinemas do not have enough funds to replace sound equipment; during this period, the films imported by the US to China are mainly sound films, and the language barriers caused obstruction of viewing. A variety of factors together provide the market space for domestic silent films to continue large-scale production.

\section{DIVERSIFIED PUBLIC OPINION GUIDANCE AND COMPLEX CONTEXTUAL DisciPLINE}

During the period of Chinese sound film production, the specific social discourse about the film provided a context for production and consumption. The historical status quo of American and domestic sound films, silent films and other art forms, social and historical conditions, and foreign movie theory concepts have jointly provided an evaluation reference for these discourses. Audio films and their specific works were included in this frame of reference for evaluation. They directly and indirectly continue to shape and influence audience and filmmakers' judgments on the necessity, potential for development, and social functions of audio films. During this period, "Film Special" of "Shen bao", "Film Weekly" in "Ta Kung Pao", "Film Times" in "Times", "Flick Daily" in "Morning paper", and "Movies and theatre" in "Min Bao" are important channels for movie criticism. At the same time, professional movie magazines such as "Star Monthly", "Artistic Film", "Yihua Weekly", "Modern Film”,

\footnotetext{
11 Luo Mingyou "Letter for the industry for the revival of China's films", "Theatrical Magazine", Vol. 1, No. 9, 1930.
} 
"Electro-acoustic", and "Diantong" have appeared successively in the form of initial publication or revision. These newspapers and movie magazines not only promoted the development of early Chinese film criticism, but also provided diversified public opinion feedback and concept guidance for the production of China's sound films.

Before the appearance of China's sound films, based on the technological change of the film and the large-scale input of American sound films, China's film criticism field have already begun to discuss and evaluate the sound films. In March 1930, in the magazine "Art Monthly" edited by Shen Duanxian (Xia Yan), Feng Naichao, Zheng Boqi, Hong Lingfei, Jiang Guangci, Ye Shen (Shen Xixi) and Dai Wanping, discussed the "prospect of the sound film". At about the same time, commentators commented on the sound films in media such as Ta Kung Pao, Silver Bullet, and Beiyang Pictorial. In the article "Sound Films Don't Fail," the author believes that the screen language barrier of sound films makes it easier to break the monopoly of Hollywood movies, and puts forward expectations for whether China will produce sound films. ${ }^{12}$ Contrary to the above attitudes, some commentators are more passive in the production of domestic sound film based on imperfect technology, huge capital investment, language barriers, and difficulty in performance. These discourses formed such topics as "sound or silent, which is superior", "whether they should be filmed," and "how to take good shots," and elaborated a series of problems such as the language barriers, technology, talent, venues, equipment, market prospects, creation tendency, and artistic characteristics and so on.

The release of the Star Film Company's wax disc dubbing sound film "Sing-song Girl Red Peony" further sparked the public opinion about the sound film. The commentary discourse published on the medium focus on "Special Issue for Sing-song Girl Red Peony" highlights the film's exemplary meaning for domestic sound films from sound, performance, plot, and language. In addition, the huge market profits brought by the film to the Star Company have greatly stimulated and inspired the China's film industry to produce the sound film. How do you view the technology and style of the emphasis on singing, dancing, dialogue, and music in early stage of sound film? Does the language barrier caused by the sound entering the movie affect the film market? How can we solve the equipment, venues, talents, technology and funds for producing sound film? In terms of artistic characteristics, is sound film the progress of silent films? Will sound films replace silent films? This series of questions is not only the focus of the commentary on the sound film, but also the anxiety of the domestic film companies in producing sound films.

Some commentators believe that people's welcome to the sound film is entirely due to a temporary curiosity, and the unreality of the screen sound will destroy the silent beauty of silent films. There are also commentators who are opposed to making sound films or think that sound films are difficult to develop due to the inconsistency of language, high

\footnotetext{
12 Jing: "The sound movie does not fail", "Silver Bullet" 19th Issue
} 5th 3-4th edition. expense, little market prospects, and difficulties in producer director, actor, collection technology, and site facilities. At the same time, there are also a large number of articles supporting and approving sound films and their production, and they disprove the view that sound films will undermine the quiet beauty of movies. For instance, in the article "Sound Films and Stars System", Ding Bai thinks that "If sound is said to destroy the quiet art, is there anyone saying that the movie is purely 'quiet'? Haven't itself destroyed its own silence? "13 In addition, Zheng Zhengqiu, Yao Sufeng, and Zhou Shoujuan and so on have pointed out that the sound and picture are not synchronized caused by the technical problems of the sound films, and that with the development of science and technology, this problem will be improved. In addition, based on the film's social function and national consciousness, some commentators believe that excellent home-made sound films are related to the "face" of Chinese people and call for "producing sound films that can compete for China"; ${ }^{14}$ "Developing Chinese sound films can

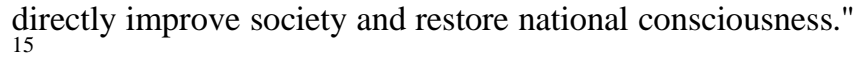

Public opinion about sound film also includes the translation of the theoretical concepts of foreign films and the introduction of sound film evaluations by foreign filmmakers. In the translation and introduction of foreign sound film theory, Hong Shen, You Zhiwu, Wang Mengou, Situ Huimin, and $\mathrm{Xu}$ Xingzhi, etc. translated the former Soviet Union and Japan articles of Pudovkin, Eisenstein, Alexander Aleklov, Cao Korov, Shimizu Hikaru, Yamato Masaru and other film theorists into Chinese and published in China's newspapers and periodicals ${ }^{16}$. These translated articles have played an important role in the promotion and popularization of domestic sound films and the development of the concept of China's sound films. Newspapers and periodicals of this period also published a series of articles to introduce the attitude and position of American filmmakers, actors, and directors to sound films.

The writers' identities, attitudes, positions, aesthetics, and social concepts cannot be ignored in exploring the generation mechanism of China's sound films. In terms of identity, they firstly existed as audience and represented the position and attitude of a part of the audience towards the sound film. At the same time, they mostly have professional identities in the fields of news, art, and film, and even include decision makers and film creators of movie companies. Such identity makes their commentary discourses targeted and practical,

\footnotetext{
13 Ding Bai, "Sound Film and Star System", fotokino magazin, 19th 1935.

14 Zheng Zhengqiu, "All Aspects for China's Audiovisual Reports," "Special Issue of Sing-song Girl Red Peony", Shanghai Warwick Trading Company, April, 1931.

15 Jing Yin "on the sound film: one of the practices for script", "Drama Monthly" 1934th 12th period.

16 The Chinese translations of these articles were published in magazines such as "Movie Monthly", "Month of Literature and Art", and "Dongtong" with the title of "The Prospect of Sound Films", "The Parallel Method and the Alignment Method of the Sound Film", "The Rhythm and Problems in Sound Films", "Asynchronism in Sound Films", "On the Actor of Sound Film", "Sound Film Becoming an Integrated Art", "The Future of the Sound Film" and "About the Sound Film".
} 
and it also enables them to play the role of "opinion leader" in the movie industry at that time.

\section{CONCLUSION}

The technical condition of China's films in the 1930s was an important factor for the long-term coexistence of China's sound films and silent films, but it was not the only factor. The trial production of China's sound film is not simply because of the decision of a single film company, or because of the production of a film. The complex situation of China's film was created by the economic and market conditions, technical conditions, public opinion discourse, and social context in which China's films were transformed from silent films to sound film. Film being regarded as the industry has become the dominant and common factor in this complex generation mechanism. This industrialism includes both the commercial and profitable purpose of the film company and the appeal of the film as part of the construction of modern nation-states. However, in China at that time, silent films still occupied an important position both in the market space and in the social influence level, which led to the special phenomenon of long-term coexistence of sound films and silent films. In 1937, China's sound film finally achieved overall popularization. However, due to the Japanese invasion of China and the fall of Shanghai, the first creative peak of China's sound film appeared only after the war.

\section{REFERENCES}

[1] Zhi Song, "History of Shanghai Movie Theater Showing Sound Film", Electroacoustic, Vol. 5, No. 36, 1936. 之松《上海电影院放映有声 电影历史》, 《电声》, 1936 年第 5 卷第 36 期。

[2] (United States) Robert C. Allen, Douglas Gomel, "Film History: Theory and Practice", Beijing: Beijing Union Press, 2016, 135-136. （美）罗伯特・C - 艾伦, 道格拉斯・戈梅里《电影史: 理论与 实践》, 北京: 北京联合出版社 2016 年版, 135-136 页。

[3] Xu Bibo, "The Beginning of Chinese Sound Films," Chinese Film, 4th Issue, 1957. '徐碧波《中国有声电影的开端》， 《中国电影》 1957 年第 4 期。

[4] Ping Baoshan, "Sound Films in East Asia", The Life of Film, Vol. 1, No. 9, 1931. 平宝善《有声电影在东亚》，《影戏生活》1931 年 第 1 卷第 9 期。

[5] Rao Shuguang, "The History of Chinese Film Market Development", Beijing: China Film Press, 2009, p. 103. 饶曙光《中国电影市场发 展史》，北京：中国电影出版社 2009 年，第 103 页。

[6] Mingyi, "The Overview of Tianyi Company and General Production", Jincheng Monthly, Volume 1, Number 4. 明夷《天一公司概况及出 品一般》, 《金城月刊》第 1 卷第 4 期。

[7] Luo Mingyou "Letter for the industry for the revival of China's films", Theatrical Magazine, Vol. 1, No. 9, 1930. 罗明佑《为国片复兴问题 敬告同业书》, 《影戏杂志》 1930 年第 1 卷第 9 期。

[8] Jing: "The sound movie does not fail", Silver Bullet 19th Issue 5th 34th edition. 敬: 《有声电影不失败》, 《银弹》1930 年第 5 期第 3-4 版。

[9] Ding Bai, "Sound Film and Star System", Fotokino Magazin, 19th, 1935. 丁白《有声电影与明星制度》, 《电影画报》1935 年第 19 期。

[10] Zheng Zhengqiu, "All Aspects for China's Audiovisual Reports," "Special Issue of Sing-song Girl Red Peony", Shanghai Warwick Trading Company, April, 1931. 郑正秋《为中国有声影片告各方 面》, 《<歌女红牡丹>特刊》, 上海华威贸易公司 1931 年 4 月。
[11] Jing Yin. "On the Sound Film: One of the Practices for Script", "Drama Monthly", 1934th 12th period. 静因《论有声电影: 剧本作 法之一》，《剧学月刊》1934 年第 12 期。 